\title{
Effects of Suspended Titanium Dioxide Nanoparticles on Cake Layer Formation in Submerged Membrane Bioreactor
}

Lijie Zhou ${ }^{\mathrm{a}}$, Zhiqiang Zhang ${ }^{\mathrm{a}, \mathrm{b}}$, Siqing Xia ${ }^{\mathrm{a} *}$, Wei Jiang ${ }^{\mathrm{c}}$, Biao $\mathrm{Ye}^{\mathrm{a}}$, Xiaoyin $\mathrm{Xu}^{\mathrm{a}}$, Zaoli Gu${ }^{\mathrm{a}}$, Wenshan Guo ${ }^{\mathrm{d}}$, Huu-Hao Ngo ${ }^{\mathrm{d}}$, Xiangzhou Meng ${ }^{\mathrm{a}}$, Jinhong Fan ${ }^{\mathrm{e}}$, Jianfu Zhao $^{\mathrm{a}}$

${ }^{a}$ State Key Laboratory of Pollution Control and Resource Reuse, College of Environmental Science and Engineering, Tongji University, Shanghai 200092, China

${ }^{b}$ Key Laboratory of Yangtze River Water Environment, Ministry of Education, College of Environmental Science and Engineering, Tongji University, Shanghai 200092, China

${ }^{c}$ Shenzhen Water Group Co. Ltd., Shenzhen 518031, China

${ }^{d}$ Centre for Technology in Water and Wastewater, School of Civil and Environmental Engineering, University of Technology, Sydney, P.O. Box 123, Broadway, NSW 2007, Australia

${ }^{e}$ State Engineering Research Center for Urban Pollution Control, College of Environmental Science and Engineering, Tongji University, Shanghai 200092, China

*Corresponding author. Tel: +8621 65980440; Fax: +86 2165986313.

E-mail address: siqingxia@gmail.com (S. XIA). 


\begin{abstract}
Effects of the suspended titanium dioxide nanoparticles $\left(\mathrm{TiO}_{2} \mathrm{NPs}, 50\right.$ $\mathrm{mg} / \mathrm{L}$ ) on the cake layer formation in a submerged MBR were systematically investigated. With nanometer sizes, $\mathrm{TiO}_{2} \mathrm{NPs}$ were found to aggravate membrane pore blocking but postpone cake layer fouling. $\mathrm{TiO}_{2}$ NPs showed obvious effects on the structure and the distribution of the organic and the inorganic compounds in cake layer. Concentrations of fatty acids and cholesterol in the cake layer increased due to the acute response of bacteria to the toxicity of $\mathrm{TiO}_{2}$ NPs. Line-analysis and dot map of energy-dispersive X-ray were also carried out. Since $\mathrm{TiO}_{2} \mathrm{NPs}$ inhibited the interactions between the inorganic and the organic compounds, the inorganic compounds (especially $\mathrm{SiO}_{2}$ ) were prevented from depositing onto the membrane surface. Thus, the postponed cake layer fouling was due to the changing features of the complexes on the membrane surface caused by $\mathrm{TiO}_{2} \mathrm{NPs}$.
\end{abstract}

Keywords: Membrane bioreactor; Titanium dioxide nanoparticles; Cake layer; Membrane fouling 


\section{Introduction}

With the rapid development and application of nanotechnology, nanoparticles (NPs) are now widely applied in industrial products(Nel et al., 2006). Particularly, titanium dioxide nanoparticles $\left(\mathrm{TiO}_{2} \mathrm{NPs}\right)$ have been widely used in catalysts, sunscreens, cosmetics and coatings (Kim \& Van der Bruggen, 2010; Lu et al., 2008; Mu \& Chen, 2011; Zhao \& Chen, 2011; Zheng et al., 2011). However, these extensive applications of $\mathrm{TiO}_{2}$ NPs inevitably induce their environmental release (Zhao \& Chen, 2011; Zheng et al., 2011). Recently, $\mathrm{TiO}_{2}$ NPs have been found to be present in air, soil, sewage as well as sludge from wastewater treatment processes (Zheng et al., 2011). Thus their potential health and environmental effects have attracted great concerns (Lu et al., 2008; Zhang et al., 2012). Concerns have also been raised about the toxicity of $\mathrm{TiO}_{2}$ NPs in human and organisms at mg/L (Kalive et al., 2012). Currently their potential effects on certain bacteria in the activated sludge of wastewater treatment plants (WWTPs) have been considered and studied. Zhao and Chen (2011) reported that $\mathrm{TiO}_{2}$ NPs improved the decomposition of protein and polysaccharide to small molecule organic compounds and promoted the growth of photosynthetic bacteria during hydrogen production from waste activated sludge. Zheng et al. (2011) showed that $50 \mathrm{mg} / \mathrm{L}$ of $\mathrm{TiO}_{2}$ NPs significantly decreased total nitrogen (TN) removal efficiency after long-term exposure, but they had no 
chronic effect on biological phosphorus removal. Hence, $\mathrm{TiO}_{2} \mathrm{NPs}$ might influence the microbial activity in membrane bioreactors (MBRs). As the major obstacle for MBR application, membrane fouling is mainly attributed to cake layer formation on the membrane surface (Guo et al., 2012; Johir et al., 2013; Meng et al., 2009; Meng et al., 2007; Wang \& Wu, 2009). Foulants in cake layer can be classified into two categories: the organic and the inorganic (Meng et al., 2007). Organic compounds, such as soluble microbial products (SMP) and extracellular polymeric substances (EPS), have aroused a wide concern in cake layer formation. Chen et al. (2006) reported that $\alpha$-polysaccharide was an important contributor to the initial cake layer formation. Protein and $\beta$-polysaccharide built up the remaining part of the cake layer. Regarding inorganic compounds, they play an important role in cake layer formation through crystallization and particulate fouling (Guo et al., 2012; Wang \& Wu, 2009). Meng et al. (2009) also pointed out that inorganic compounds of wastewater were in close relation with the formation of precipitation and cake layer. Generally, the inorganic fouling could be irreversible and more difficult to be eliminated even by chemical cleaning (Guo et al., 2012).

It was stated that low-fouling or functional membranes using various nanoparticles (mainly $\mathrm{TiO}_{2}$ NPs) have been developed and widely applied in membrane filtration process (Kim \& Van der Bruggen, 
2010). Due to photocatalytic property of $\mathrm{TiO}_{2} \mathrm{NPs}$, research has been focused on fabricating nanocomposite membrane containing $\mathrm{TiO}_{2} \mathrm{NPs}$ to improve the properties of polymer materials, enhanced permeability and decrease fouling-resistance (Kim \& Van der Bruggen, 2010; Li et al., 2009; Zhang \& Yang, 2012; Zhang et al., 2011). However, there are very few studies about the potential effects of suspended $\mathrm{TiO}_{2}$ NPs on cake layer formation in MBR.

The aim of this study was to gain insight into the effects of suspended $\mathrm{TiO}_{2} \mathrm{NPs}$ on cake layer formation on the membrane surface in a submerged MBR. The variations of both transmembrane pressure (TMP) and membrane resistances were measured to determine the responses of the cake layer to $\mathrm{TiO}_{2}$ NPs. Both organic and inorganic foulants in the cake layer were also characterized via various methods, including Fourier transform infrared spectroscopy (FTIR), gas chromatography-mass spectrometry (GC-MS), scanning electron microscopy (SEM), X-ray diffraction analysis (XRD), etc. In addition, the effects of the cake layer formed by $\mathrm{TiO}_{2}$ NPs were analyzed using both dot map and line-analysis of energy-dispersive X-ray (EDX). 


\section{Materials and methods}

\subsection{Preparation of $\mathrm{TiO}_{2}$ NPs suspension}

Commercially available $\mathrm{TiO}_{2}$ NPs were purchased from Sigma-Aldrich. XRD analysis was conducted using a Rigaku D/Max-RB diffractometer equipped with a rotating anode and a $\mathrm{Cu} K \mathrm{KR}$ radiation source (Bruker,Optik $\mathrm{GmbH}$, Ettlingen, Germany), and the XRD pattern of $\mathrm{TiO}_{2}$ NPs was shown in Fig. S1 (supporting information, SI). The structure of $\mathrm{TiO}_{2}$ NPs was visualized through the transmission electron microscopy (TEM) image using a Tecnai F20 (Philips Eletron Optics, Netherlands) with a $200 \mathrm{kV}$ accelerating voltage (Fig. S2). The primary size of $\mathrm{TiO}_{2}$ NPs in stock suspension was in the range of $20 \mathrm{~nm}$, which was similar to the particle size provided by Sigma-Aldrich. The $\mathrm{TiO}_{2}$ NPs stock suspension $(100 \mathrm{mg} / \mathrm{L})$ was prepared by adding $100 \mathrm{mg}$ of $\mathrm{TiO}_{2}$ NPs to $1 \mathrm{~L}$ of Milli-Q water, followed by $1 \mathrm{~h}$ ultrasonication $(25$ ${ }^{\circ} \mathrm{C}, 300 \mathrm{~W}, 40 \mathrm{kHz}$ ) according to the literature (Keller et al., 2010). Zheng et al. (2011) found that significant loss of bacterial viability was NP concentration-dependent after bacteria were exposed to the relatively small size of $\mathrm{TiO}_{2} \mathrm{NPs}$ (diameter ranged from 10 to $25 \mathrm{~nm}$ ). $\mathrm{TiO}_{2} \mathrm{NPs}$ concentration of 1,10 and $50 \mathrm{mg} / \mathrm{L}$ were chosen in our study, and showed the same result. Due to $50 \mathrm{mg} / \mathrm{L} \mathrm{TiO}_{2}$ NPs showed obvious effects on the bacterial viability, it was chosen in this study (Some results of 1 and $10 \mathrm{mg} / \mathrm{L} \mathrm{TiO}_{2} \mathrm{NPs}$ are showed in the $\mathrm{SI}$ ). 
The influent was synthetized with tap water, containing $420 \mathrm{mg} / \mathrm{L}$ glucose, $420 \mathrm{mg} / \mathrm{L}$ corn starch, $102.75 \mathrm{mg} / \mathrm{L} \mathrm{NH} \mathrm{NH}_{4} \mathrm{Cl}$ and $22 \mathrm{mg} / \mathrm{L}$ $\mathrm{KH}_{2} \mathrm{PO}_{4}$ as well as trace nutrients such as $\mathrm{CaCl}_{2}(8 \mathrm{mg} / \mathrm{L}), \mathrm{MgSO}_{4} \cdot 7 \mathrm{H}_{2} \mathrm{O}$ $(9 \mathrm{mg} / \mathrm{L}), \mathrm{MnSO}_{4} \cdot \mathrm{H}_{2} \mathrm{O}(3.66 \mathrm{mg} / \mathrm{L})$ and $\mathrm{FeSO}_{4} \cdot 7 \mathrm{H}_{2} \mathrm{O}(0.55 \mathrm{mg} / \mathrm{L})$. $\mathrm{NaHCO}_{3}$ was used as a buffer to adjust the influent $\mathrm{pH}$ of to about 7.0.

\subsection{Set-up and operation of MBRs}

Two identical submerged MBRs (MBR-NPs and MBR-Blank) (3 L working volume, $20 \mathrm{~cm} \times 10 \mathrm{~cm} \times 25 \mathrm{~cm}$ of length $\times$ width $\times$ height) were used in this study. $2 \mathrm{~L}$ of inoculation sludge obtained from Quyang WWTP (Shanghai, China) was added in each bioreactor and then the stable biological pollutants removal (approximately $90 \%$ of both COD and ammonia nitrogen removal) was achieved before starting the experiment. MBR-NPs was initially fed with $\mathrm{TiO}_{2}$ NPs stock suspension $(100 \mathrm{mg} / \mathrm{L})$ in order to reach the predetermined $\mathrm{TiO}_{2} \mathrm{NPs}$ concentration of $50 \mathrm{mg} / \mathrm{L}$, and the operational time was recorded when MBR-NPs performance was stable $\left(\mathrm{TiO}_{2} \mathrm{NPs}\right.$ were directly added into MBR-NPs during operation and the influent was without $\mathrm{TiO}_{2} \mathrm{NPs}$ ). Because the concentration of $\mathrm{TiO}_{2}$ NPs in MBR-NPs might slowly decrease due to the discharge of effluent or sludge, a certain amount of $\mathrm{TiO}_{2}$ NPs stock suspension $(100 \mathrm{mg} / \mathrm{L})$ were supplemented every day for maintaining the initial $\mathrm{TiO}_{2} \mathrm{NPs}$ concentration $(50 \mathrm{mg} / \mathrm{L})$ after determining the total 
concentration of $\mathrm{TiO}_{2}$ in MBR-NPs. MBR-Blank was operated as the control unit (i.e., without $\mathrm{TiO}_{2}$ NPs addition). A hollow fiber PVDF membrane module $\left(0.02 \mathrm{~m}^{2}\right.$ total surface area and $0.1 \mu \mathrm{m}$ pore size, manufactured by Li-tree Company, Suzhou, China), was immersed in each MBR. Air $\left(0.4 \mathrm{~m}^{3} / \mathrm{h}\right)$ was continuously supplied through a perforated pipe under the membrane module. Peristaltic pump equipped with distributing pan was employed to control the influent feeding rate. Hydraulic retention time (HRT) and solids retention time (SRT) was remained at $8.0 \mathrm{~h}$ and 30 days for two MBRs. Mixed liquor suspended solids (MLSS) in MBR-NPs and MBR-Blank were 5170 $\pm 340 \mathrm{mg} / \mathrm{L}$ and $5014 \pm 275 \mathrm{mg} / \mathrm{L}$, respectively, during operation. Additionally the flux in two reactors was maintained at $45 \mathrm{~L} /\left(\mathrm{m}^{2} \cdot \mathrm{h}\right)$ by an intermittent suction mode with 10 minutes of suction followed by 2 minutes relaxation. When the TMP reached $40 \mathrm{kPa}$, the membrane module was removed for physical (tap water washing) and chemical cleaning (2\% $\mathrm{NaOCl}$ and $1 \%$ citric acid immersion for $4 \mathrm{~h}$, respectively (Johir et al., 2013)) prior to the next run. The influent and effluent qualities in two MBRs were summarized in Table S1 and Table S2.

\subsection{Analytical methods}

The determination of ammonia nitrogen $\left(\mathrm{NH}_{4}{ }^{+}-\mathrm{N}\right)$, total organic carbon (TOC), total nitrogen (TN), and mixed liquor suspended solid 
(MLSS) were conducted in accordance with the Standard Methods (China-NEPA, 2002). The concentration of $\mathrm{TiO}_{2}$ NPs in MBR-NPs and effluent was analyzed via an inductively coupled plasma-optical emission spectrometer (ICP-OES, Optima 2100 DV, Perkin Elmer, USA) according to Zheng et al (2001). The analyses of membrane resistances, three-dimensional excitation-emission matrix (EEM) fluorescence spectroscopy, FTIR, GC-MS, EPS and SEM-EDX were detailed in the SI.

\section{Results and discussion}

\subsection{Membrane permeability in submerged MBR}

Directly reflecting the membrane filterability, the TMP of MBR is an important parameter in evaluating the situation of membrane fouling. The TMP variations of two MBRs throughout the 80-days operation were presented in Fig. 1. Membrane fouling is attributed to two-step fouling phenomenon, i.e., initial slight TMP increase (first step) followed by a rapid one (second step). For both MBRs, the TMP remained at steady low value (about $1-3 \mathrm{kPa}$ ) in the first step, then increased rapidly, and finally reached $40 \mathrm{kPa}$ (when the membrane module was deemed to be severe fouled) in the second step. According to the traditional membrane fouling mechanism (Meng et al., 2009; Wang \& Wu, 2009), in the first step, membrane pore blocking occurred 
on the porous surface followed with gel layer formation (it could be considered as the initial cake layer formation stage), and the TMP was in steady state with slight increase. In the second step, a cake layer forms on the membrane surface, leading to a rapid increase in TMP. As can been seen from Fig. 1, the membrane fouling was postponed in MBR-NPs, which presented a longer period of first step than MBR-Blank. Additionally, the TMP increase rate $(d \mathrm{TMP} / d \mathrm{t})$ of MBR-NPs $(2.3 \mathrm{kPa} / \mathrm{d})$ was lower than that of MBR-Blank $(3.8 \mathrm{kPa} / \mathrm{d})$ during the second step. It indicated that the presence of $\mathrm{TiO}_{2} \mathrm{NPs}$ could reduce the TMP rise and postpone membrane fouling during operation.

\section{Fig. 1}

\section{Table 1}

According to recent reviews, pore blocking results in irreversible fouling, but the formation of cake layer is mainly caused by reversible foulants which can be removed by physical cleaning (Guo et al., 2012; Meng et al., 2009; Wang \& Wu, 2009). Thus, the fouling resistance (showed in Table 1) was calculated on the basis of permeation data and resistance-in-series model (Johir et al., 2013; Lee et al., 2001). In MBR-Blank, the total resistance $\left(R_{t}\right)$ and cake resistance $\left(R_{c}\right)$ were 
around 1.7 times of those in MBR-NPs, indicating that the reactor without $\mathrm{TiO}_{2}$ NPs addition suffered from more severe membrane fouling. Although the presence of $\mathrm{TiO}_{2} \mathrm{NPs}$ in MBR increased the contribution of the pore blocking resistance to the total resistance $(5 \%)$, it decreased the contribution of the cake resistance by $8.2 \%$ at the same time. Hence, $\mathrm{TiO}_{2}$ NPs addition could aggravate the membrane pore blocking but postpone the cake layer fouling.

To further explain the effects of $\mathrm{TiO}_{2}$ NPs on the cake layer structure, identification and characterization of the fouling compounds was discussed in the following sections.

\subsection{Organic compounds in the cake layer formation}

Organic compounds play a significant role in the formation and the structure of cake layer (Meng et al., 2009; Wang \& Wu, 2009). They can physically blind the membrane surface, block the pores, attach to the membrane through adsorption, and hinder transport to the surface by the development of a cake layer (Guo et al., 2012; Meng et al., 2007).

The FTIR spectrum analyses of the biopolymers in the cake layer (Fig. S3) were carried out to characterize the major functional groups of the organic fouling compounds. The spectrum presented a broad region of absorption at $3396.0 \mathrm{~cm}^{-1}$, which was attributed to the $\mathrm{O}-\mathrm{H}$ bond stretching in hydroxyl functional groups, and a sharper peak at 2923.5 
$\mathrm{cm}^{-1}$, indicating C-H bonds stretching (Kumar et al., 2006). Additionally, as fouling compounds might contain amino sugars (i.e. $\mathrm{N}$-acetyl groups) and polysaccharides derived from bacteria (Meng et al., 2007), two peaks $\left(1652.2 \mathrm{~cm}^{-1}\right.$ and $\left.1541.9 \mathrm{~cm}^{-1}\right)$, namely amides I and II, were unique to the protein secondary structure (Maruyama et al., 2001). Besides, a broad peak at $1043.5 \mathrm{~cm}^{-1}$ exhibited the character of carbohydrates or carbohydrates-like substances (Croue et al., 2003). Thus, the data indicated that both of protein and carbohydrate were the components of the organic foulants in the cake layer, no matter whether $\mathrm{TiO}_{2}$ NPs are present or not. The functional groups with the sharp peak at $675.1 \mathrm{~cm}^{-1}$, was due to stretching of Ti-O bonds (Zhang \& Yang, 2012), indicated that $\mathrm{Ti}$ ions might bind to the biopolymers in the cake layer (Kim \& Van der Bruggen, 2010).

\section{Fig. 2}

During membrane filtration, the organic fouling compounds mainly attributes to humic and fulvic acid, hydrophilic and hydrophobic materials and proteins (Guo et al., 2012). Thus, EEM analysis of biopolymers in cake layer of rectors was carried out and the results were showed in Fig. 2. It was evident that two peaks for MBR-NPs can be clearly identified from the EEM fluorescence spectra compared to 
MBR-Blank. Peak A was identified at the excitation/emission $\left(\mathrm{E}_{\mathrm{x}} / \mathrm{E}_{\mathrm{m}}\right)$ of 275-280/320-330 nm, while Peak $B$ was located at the $E_{x} / E_{m}$ of 220-235/320-340 $\mathrm{nm}$. The two peaks have been reported as protein-like substances in which the florescence was associated with the tryptophan (Peak A) and the tyrosine (Peak B) (Tang et al., 2010). The cake layer of MBR-NPs contained more protein-like substances (tryptophan and tyrosine). For further study, EPS analyses (represented as polysaccharide, protein and humic acid (represented as TOC)) of cake layer in the two MBRs were carried out. MBR-NPs (45.32 mg/g (cake layer) polysaccharide, $61.62 \mathrm{mg} / \mathrm{g}$ (cake layer) protein and $306.12 \mathrm{mg} / \mathrm{g}$ (cake layer) TOC) had higher EPS concentration of cake layer than MBR-Blank (33.61 mg/g (cake layer) polysaccharide, $32.83 \mathrm{mg} / \mathrm{g}$ (cake layer) protein and $236.33 \mathrm{mg} / \mathrm{g}$ (cake layer) TOC). The results might be due to the agglomeration of $\mathrm{TiO}_{2}$ NPs in biological media (Deng et al., 2009). Moreover, nanoparticles (mainly $\mathrm{TiO}_{2}$ and $\mathrm{ZnO}$ ) could induce oxidative-nitrative stress, and increase intracellular reactive oxygen concentration, which could be toxic to proteins and cause bacteria to release more protein for self-protection through quorum sensing (Lu et al., 2008; Mu \& Chen, 2011; Xia et al., 2012). Wang et al. (2009) reported that EPS were identified as proteins, visible humic acid-like substances and fulvic acid-like substances. Tang et al. (2007) also stated that protein-like substances played a significant role in the cake layer 
formation, which agreed well with the finding from this study. However, MBR-NPs had high-concentration EPS in the cake layer but slow membrane fouling rate, which was opposite to the above papers (Tang et al., 2007; Wang et al., 2009). High concentration EPS in the cake layer, which was induced by $\mathrm{TiO}_{2} \mathrm{NPs}$, did not lead to the aggravation of membrane fouling in MBR-NPs. It was different from the conclusion that high concentration EPS caused severe membrane fouling (Meng et al., 2009). It indicated that $\mathrm{TiO}_{2} \mathrm{NPs}$ might also induce other behaviors affecting membrane fouling process.

\section{Table 2}

Furthermore, the volatile organic compounds in the cake layer of MBR-NPs were also analyzed by GC-MS. Both fragments and peak areas of the cake layer samples of both MBRs were identified and listed in Table 2. The volatile organic compounds of the cake layer could be categorized into fatty acids (FA), n-alkane (NA) and cholesterol (CT), all of which were the main and common volatile organic compounds released from bacteria in sewage sludge (Jarde et al., 2005). The weight percentages of FA and CT in organic compounds of the cake layer of MBR-NPs were higher (36.9\% and 37.5\%) than those (25.6\% and $0 \%)$ in MBR-Blank, respectively, whereas MBR-NPs had lower weight 
percentage of NA (25.6\%) than MBR-Blank (74.0\%). Moreover, more types of FA and CT compounds were found in the cake layer of MBR-NPs, which pointed out $\mathrm{TiO}_{2}$ NPs could induce the release of FA and CT from bacteria. A range of primarily gram negative bacteria in the cellular membrane could shift their release of FA and CT so as to response to the changes of environmental conditions, especially with toxicant shock (Petersen et al., 2003). In addition, FA and CT from bacteria are prone to membrane fouling because they could complicate the deposition of organic compounds on membrane surface (Al-Halbouni et al., 2009; Ang \& Elimelech, 2008). Therefore, $\mathrm{TiO}_{2} \mathrm{NPs}$ changed the distribution of the volatile organic compounds in the cake layer, especially increasing the weight percentage of FA and CT in the cake layer.

\subsection{Inorganic compounds in cake layer formation}

Although most of the foulants in MBR are classified as organic compounds (Meng et al., 2009), inorganic compounds can cause fouling when precipitation occurs on the membrane due to hydrolysis and oxidation during filtration. Particularly, they can exert significant influence on the initial fouling (Guo et al., 2012; Meng et al., 2009). Additionally, inorganic compounds also play a significant role in the cake layer formation, especially in the desalination and reverse osmosis 
systems (Demadis et al., 2005; Guo et al., 2012). Some reviews presented that inorganic metal ions, such as $\mathrm{Ca}, \mathrm{Mg}$, Si, etc., had similar behaviors on capturing negative ions and analogous fouling mechanism (Guo et al., 2012; Meng et al., 2009). Li et al. (2012) found that $\mathrm{Si}$ formed anhydrides through the reaction with the organic compounds on the membrane surface, which aggravated the membrane fouling. However, there are very few studies to make clear the inorganic compounds distribution in cake layer formation.

To verify the inorganic compounds distribution on the cake layer with $\mathrm{TiO}_{2}$ NPs addition, the elemental analysis was performed to identify the major compositions of the inorganic foulants. The elements such as $\mathrm{C}, \mathrm{O}, \mathrm{Na}, \mathrm{Mg}, \mathrm{Al}, \mathrm{Si}, \mathrm{Ca}, \mathrm{Ti}$ and $\mathrm{Fe}$ were detected through dot map of EDX (Table 3). The composition analysis presented that certain amounts of inorganic elements (excluding $\mathrm{C}$ and $\mathrm{O}$, which mainly presented organic compounds) were accumulated in the cake layer. $\mathrm{Si}$ was the major composition of inorganic compounds in both MBRs due to the silican deposition. It was because the major inorganic in the sludge (Table S2) was $\mathrm{Si}$ (mainly $\mathrm{SiO}_{2}$, indicated by Fig. S4), which was mainly from the initial sludge. However, MBR-NPs had less Si distribution than MBR-Blank, pointing out that $\mathrm{TiO}_{2} \mathrm{NPs}$ could inhibit the $\mathrm{Si}$ deposition onto the cake layer. $\mathrm{As}_{\mathrm{SiO}_{2}}$ has been considered as a challenge for membrane filtration due to its deposition (Demadis et al., 
2005; Meng et al., 2007), the further analysis of $\mathrm{SiO}_{2}$ in the cake layer was measured using XRD (Fig. S5) and ICP. The broad and dispersed peak suggested that the major form of $\mathrm{Si}$ and Ti presented in cake layer were crystal particles of $\mathrm{SiO}_{2}$ and $\mathrm{TiO}_{2}$, while reactive silica $(5.31 \mu \mathrm{g} / \mathrm{g}$ (cake layer)) or monosilicic acid (1.73 $\mu \mathrm{g} / \mathrm{g}$ (cake layer)) could be ignored in comparison to crystal particles of $\mathrm{SiO}_{2}(95.53 \mathrm{mg} / \mathrm{g}$ (cake layer)). Therefore, the crystal particles of $\mathrm{SiO}_{2}$, depositing into the membrane pores and on the membrane surface due to suction force during the filtration, was the major inorganic compound in the cake layer. Additionally, the addition of $\mathrm{TiO}_{2} \mathrm{NPs}$ reduced the $\mathrm{SiO}_{2}$ content in the cake layer, indicating that $\mathrm{TiO}_{2}$ NPs could postpone the fouling caused by $\mathrm{SiO}_{2}$ during the cake layer formation.

\section{Table 3}

For further study the change of inorganic compounds during the cake layer formation, the inorganic elements distributions along the cross-section of the cake layer in two MBRs were conducted by line-analysis of EDX (Fig. S6) (The EDX line-analyses with 1 and 10 $\mathrm{mg} / \mathrm{L} \mathrm{TiO}_{2}$ NPs were also showed in Fig. S7). The thickness of the cake layer in MBR-Blank $(88 \mu \mathrm{m})$ was almost twice of that in MBR-NPs (46 $\mu \mathrm{m})$, elucidating that MBR-Blank suffered more severe membrane 
fouling (the cross-section of the virgin membrane was showed in Fig. S8). As the Ti distribution was showed in Fig. $\mathrm{S} 6, \mathrm{TiO}_{2} \mathrm{NPs}$ were more concentrated near the interface of membrane surface in the cake layer of MBR-NPs. Fig. S6 also displayed that $\mathrm{SiO}_{2}$ was mainly distributed in 0-40 $\mu \mathrm{m}$ cake layer in two MBRs, which verified that the principal inorganic compounds (mainly $\mathrm{SiO}_{2}$ ) were mainly contributed to the initial cake layer formation. The comparison of Si distribution between two MBRs indicated less $\mathrm{SiO}_{2}$ containing and the nonuniform $\mathrm{SiO}_{2}$ distribution in the initial cake layer formation of MBR-NPs.

According to the above phenomenon, the addition of $\mathrm{TiO}_{2} \mathrm{NPs}$ prevented Si from depositing onto the membrane surface. Although the concentrations of $\mathrm{Ca}$ and $\mathrm{Mg}$ were relatively low in the cake layer of both MBRs (Table 3 and Fig. S6), $\mathrm{TiO}_{2}$ NPs also had a similar effect on their distributions in the cake layer. It might be caused by the bidentate coordination of $-\mathrm{COOH}$ in the organic compounds to $\mathrm{TiO}_{2}$ and the other inorganic compounds (Fig. S9) (Kim \& Van der Bruggen, 2010). For example, from the crystal chemistry (Chen, 2010), silicon with a stable atomic structure has smaller ionic radius and lower electronegativity than titanium. Hence, it is easier for titanium than for silicon to react with the functional groups of the organic compounds attached onto the membrane surface, such as $-\mathrm{COOH}$ and $-\mathrm{OH}$. Compared with other particles $\left(\mathrm{SiO}_{2}, \mathrm{CaCO}_{3}\right.$, etc.), nanoparticles (mainly $\mathrm{TiO}_{2} \mathrm{NPs}$ ) have 
stronger adsorbability and oxidation capability to the organic compounds (Kim \& Van der Bruggen, 2010). Therefore, $\mathrm{TiO}_{2} \mathrm{NPs}$ show a strong tendency to combine with the organic compounds (macromolecules, proteins, and FA), and attached onto the membrane surface during the initial cake layer $(0-20 \mu \mathrm{m})$ formation.

\section{Conclusions}

$\mathrm{TiO}_{2}$ NPs had obvious effects on the cake layer formation on the membrane surface. $\mathrm{TiO}_{2}$ NPs aggravated the membrane pore blocking but postponed the cake layer fouling. Concentrations of FA and CT in the cake layer increased due to the acute response of bacteria to the toxicity of $\mathrm{TiO}_{2}$ NPs. Inorganic compounds (especially $\mathrm{SiO}_{2}$ ) were prevented from depositing onto the membrane surface as a result of $\mathrm{TiO}_{2}$ NPs inhibiting the interactions between the inorganic and the organic compounds. $\mathrm{TiO}_{2}$ NPs changed the features of the complexes on the membrane surface, leading to the postponement of cake layer fouling.

\section{Acknowledgements}

The authors sincerely thank the support of the National Science \& Technology Pillar Program (2013BAD21B03), the Fundamental Research Funds for the Central Universities, Shanghai Shuguang Tracking Program (10GG12), and $1^{\text {st }}$ World Membrane Bioreactor 
(MBR) Centre.

\section{References}

1. Al-Halbouni, D., Dott, W., Hollender, J. 2009. Occurrence and composition of extracellular lipids and polysaccharides in a full-scale membrane bioreactor. Water Research, 43(1), 97-106.

2. Ang, W.S., Elimelech, M. 2008. Fatty acid fouling of reverse osmosis membranes: Implications for wastewater reclamation. Water Research, 42(16), 4393-4403.

3. Chen, J.Z. 2010. Modern Crystal Chemisty. 1st ed. in: Modern chemical foundation series, (Ed.) Q.S. Zhu, Vol. 20, Science Press. Beijing, pp. 202-204.

4. Chen, M.Y., Lee, D.J., Tay, J.H. 2006. Extracellular polymeric substances in fouling layer. Separation Science and Technology, 41(7), 1467-1474.

5. China-NEPA. 2002. Water and Wastewater Monitoring Methods. 4th ed ed, Chinese Enviromental Science Publishing House. Beijing, China.

6. Croue, J.P., Benedetti, M.F., Violleau, D., Leenheer, J.A. 2003. Characterization and copper binding of humic and nonhumic organic matter isolated from the South Platte River: Evidence for the presence of nitrogenous binding site. Environmental Science \& 
Technology, 37(2), 328-336.

7. Demadis, K.D., Neofotistou, E., Mavredaki, E., Tsiknakis, M., Sarigiannidou, E.M., Katarachia, S.D. 2005. Inorganic foulants in membrane systems: chemical control strategies and the contribution of "green chemistry". Desalination, 179(1-3), 281-295.

8. Deng, Z.J., Mortimer, G., Schiller, T., Musumeci, A., Martin, D., Minchin, R.F. 2009. Differential plasma protein binding to metal oxide nanoparticles. Nanotechnology, 20(45).

9. Guo, W., Ngo, H.-H., Li, J. 2012. A mini-review on membrane fouling. Bioresource Technology, 122(0), 27-34.

10. Jarde, E., Mansuy, L., Faure, P. 2005. Organic markers in the lipidic fraction of sewage sludges. Water Research, 39(7), 1215-1232.

11. Johir, M.A., Shanmuganathan, S., Vigneswaran, S., Kandasamy, J. 2013. Performance of submerged membrane bioreactor (SMBR) with and without the addition of the different particle sizes of GAC as suspended medium. Bioresource Technology, 141, 13-18.

12. Kalive, M., Zhang, W., Chen, Y.S., Capco, D.G. 2012. Human intestinal epithelial cells exhibit a cellular response indicating a potential toxicity upon exposure to hematite nanoparticles. Cell Biology and Toxicology, 28(5), 343-368.

13. Keller, A.A., Wang, H.T., Zhou, D.X., Lenihan, H.S., Cherr, G., Cardinale, B.J., Miller, R., Ji, Z.X. 2010. Stability and Aggregation 
of Metal Oxide Nanoparticles in Natural Aqueous Matrices. Environmental Science \& Technology, 44(6), 1962-1967.

14. Kim, J., Van der Bruggen, B. 2010. The use of nanoparticles in polymeric and ceramic membrane structures: Review of manufacturing procedures and performance improvement for water treatment. Environmental Pollution, 158(7), 2335-2349.

15. Kumar, M., Adham, S.S., Pearce, W.R. 2006. Investigation of seawater reverse osmosis fouling and its relationship to pretreatment type. Environmental Science \& Technology, 40(6), 2037-2044.

16. Lee, J., Ahn, W.Y., Lee, C.H. 2001. Comparison of the filtration characteristics between attached and suspended growth microorganisms in submerged membrane bioreactor. Water Research, 35(10), 2435-2445.

17. Li, J.F., Xu, Z.L., Yang, H., Yu, L.Y., Liu, M. 2009. Effect of TiO2 nanoparticles on the surface morphology and performance of microporous PES membrane. Applied Surface Science, 255(9), $4725-4732$.

18. Li, Z.Y., Yangali-Quintanilla, V., Valladares-Linares, R., Li, Q.Y., Zhan, T., Amy, G. 2012. Flux patterns and membrane fouling propensity during desalination of seawater by forward osmosis. Water Research, 46(1), 195-204.

19. Lu, N.H., Zhu, Z.N., Zhao, X.Q., Tao, R., Yang, X.L., Gao, Z.H. 
2008. Nano titanium dioxide photocatalytic protein tyrosine nitration: A potential hazard of $\mathrm{TiO}(2)$ on skin. Biochemical and Biophysical Research Communications, 370(4), 675-680.

20. Maruyama, T., Katoh, S., Nakajima, M., Nabetani, H., Abbott, T.P., Shono, A., Satoh, K. 2001. FT-IR analysis of BSA fouled on ultrafiltration and microfiltration membranes. Journal of Membrane Science, 192(1-2), 201-207.

21. Meng, F.G., Chae, S.R., Drews, A., Kraume, M., Shin, H.S., Yang, F.L. 2009. Recent advances in membrane bioreactors (MBRs): Membrane fouling and membrane material. Water Research, 43(6), $1489-1512$.

22. Meng, F.G., Zhang, H.M., Yang, F.L., Liu, L.F. 2007. Characterization of cake layer in submerged membrane bioreactor. Environmental Science \& Technology, 41(11), 4065-4070.

23. Mu, H., Chen, Y. 2011. Long-term effect of $\mathrm{ZnO}$ nanoparticles on waste activated sludge anaerobic digestion. Water Research, 45(17), $5612-5620$.

24. Nel, A., Xia, T., Madler, L., Li, N. 2006. Toxic potential of materials at the nanolevel. Science, 311(5761), 622-627.

25. Petersen, S.O., Henriksen, K., Mortensen, G.K., Krogh, P.H., Brandt, K.K., Sorensen, J., Madsen, T., Petersen, J., Gron, C. 2003. Recycling of sewage sludge and household compost to arable land: 
fate and effects of organic contaminants, and impact on soil fertility. Soil \& Tillage Research, 72(2), 139-152.

26. Tang, C.Y.Y., Kwon, Y.N., Leckie, J.O. 2007. Characterization of humic acid fouled reverse osmosis and nanofiltration membranes by transmission electron microscopy and streaming potential measurements. Environmental Science \& Technology, 41(3), 942-949.

27. Tang, S., Wang, Z., Wu, Z., Zhou, Q. 2010. Role of dissolved organic matters $(\mathrm{DOM})$ in membrane fouling of membrane bioreactors for municipal wastewater treatment. Journal of Hazardous Materials, 178(1), 377-384.

28. Wang, Z.W., Wu, Z.C. 2009. A Review of Membrane Fouling in MBRs: Characteristics and Role of Sludge Cake Formed on Membrane Surfaces. Separation Science and Technology, 44(15), $3571-3596$.

29. Wang, Z.W., Wu, Z.C., Tang, S.J. 2009. Extracellular polymeric substances (EPS) properties and their effects on membrane fouling in a submerged membrane bioreactor. Water Research, 43(9), 2504-2512.

30. Xia, S.Q., Zhou, L.J., Zhang, Z.Q., Li, J.X. 2012. Influence and mechanism of $\mathrm{N}$-(3-oxooxtanoyl)-L-homoserine lactone ( $\mathrm{C}_{8}$-oxo-HSL $)$ on biofilm behaviors at early stage. Journal of 
Environmental Sciences-China, 103(10), 3828-3833.

31. Zhang, H., Yang, L. 2012. Immobilization of nanoparticle titanium dioxide membrane on polyamide fabric by low temperature hydrothermal method. Thin Solid Films, 520(18), 5922-5927.

32. Zhang, H.F., Liu, H.P., Zhang, L.H. 2011. Applied research of nanocomposite membrane on fouling mitigation in membrane bioreactor. Advanced materials Research, 183-185, 2019-2023.

33. Zhang, W., Crittenden, J., Li, K.G., Chen, Y.S. 2012. Attachment Efficiency of Nanoparticle Aggregation in Aqueous Dispersions: Modeling and Experimental Validation. Environmental Science \& Technology, 46(13), 7054-7062.

34. Zhao, Y.X., Chen, Y.G. 2011. Nano-TiO2 Enhanced Photofermentative Hydrogen Produced from the Dark Fermentation Liquid of Waste Activated Sludge. Environmental Science \& Technology, 45(19), 8589-8595.

35. Zheng, X., Chen, Y., Wu, R. 2011. Long-term effects of titanium dioxide nanoparticles on nitrogen and phosphorus removal from wastewater and bacterial community shift in activated sludge. Environmental Science \& Technology, 45(17), 7284-7290. 


\section{Table Captions}

Table 1. Analysis Results of Membrane Resistance $\left(R_{m}\right)$, Pore-Blocking Resistance $\left(R_{p}\right)$, Cake Resistance $\left(R_{c}\right)$, and Total Resistance $\left(R_{t}\right)$

Table 2. The Peak of the Fragments of Cake Layer in MBR-NPs and MBR-Blank by GC-MS

Table 3. Element analyses of the cake layer in MBR-NPs and MBR-Blank (Wt $(\%))$

Figure Captions

Fig. 1. TMP variation of MBR-NPs and MBR-Blank

Fig. 2. EEM fluorescence spectra of biopolymers in cake layer 
Table 1. Analysis Results of Membrane Resistance $\left(R_{\mathrm{m}}\right)$,

Pore-Blocking Resistance $\left(\boldsymbol{R}_{\mathrm{p}}\right)$, Cake Resistance $\left(\boldsymbol{R}_{\mathrm{c}}\right)$, and Total Resistance $\left(\boldsymbol{R}_{\mathrm{t}}\right)$

\begin{tabular}{cccccc}
\hline & \multicolumn{2}{c}{ MBR-NPs } & & \multicolumn{2}{c}{ MBR-Blank } \\
\cline { 2 - 3 } \cline { 5 - 6 } Item & value & percentage & & Value & percentage \\
& $\left(\mathbf{1 0}^{\mathbf{1 2}} \mathbf{m}^{-\mathbf{1}}\right)$ & $(\boldsymbol{\%})$ & & $\left(\mathbf{1 0}^{\mathbf{1 2}} \mathbf{m}^{-\mathbf{1}}\right)$ & $(\boldsymbol{\%})$ \\
\hline $\boldsymbol{R}_{\mathbf{m}}$ & 0.23 & 3.3 & & 0.23 & 2.1 \\
$\boldsymbol{R}_{\mathbf{p}}$ & 0.64 & 9.5 & & 0.27 & 4.5 \\
$\boldsymbol{R}_{\mathbf{c}}$ & 5.89 & 87.2 & & 10.30 & 95.4 \\
$\boldsymbol{R}_{\mathbf{t}}$ & 6.75 & 100 & & 10.80 & 100 \\
\hline
\end{tabular}


Table 2. The Peak of the Fragments of Cake Layer in MBR-NPs and MBR-Blank by GC-MS

\begin{tabular}{|c|c|c|c|c|c|c|c|}
\hline \multirow{2}{*}{ Items } & \multicolumn{3}{|c|}{ MBR-NPs } & \multirow{2}{*}{ Items } & \multicolumn{3}{|c|}{ MBR-Blank } \\
\hline & & Retain time & Peak Area $(\%)$ & & & Retain time & Peak Area $(\%)$ \\
\hline Hexadecanoic acid & FA & 11.59 & 14.3 & Petandecane & NA & 8.83 & 2.7 \\
\hline 10-methyl-Eicosane & NA & 12.45 & 2.8 & Hexadecanoic acid, methyl ester & FA & 11.24 & 13.8 \\
\hline 10-Octadecenoic acid & FA & 12.50 & 2.0 & Heneicosane & NA & 12.09 & 3.9 \\
\hline Octadecanoic acid & FA & 12.76 & 5.1 & Hepatadecane & NA & 12.98 & 3.9 \\
\hline Docosane & NA & 12.92 & 4.0 & $9,12,15$-Octaecatrienoic acid & FA & 13.7 & 12.1 \\
\hline Tricosane & NA & 13.37 & 5.7 & Nonadecane & NA & 14.22 & 30.8 \\
\hline Tetracosane & NA & 13.79 & 5.2 & Tetracaosane,11-decyl- & NA & 14.66 & 10.8 \\
\hline & & & & Hexadecane & NA & 9.44 & 7.4 \\
\hline & & & & $\begin{array}{l}\text { Hexadecane,2,6,10, } \\
\text { 14-tetramethyl }\end{array}$ & NA & 10.63 & 2.77 \\
\hline
\end{tabular}

\footnotetext{
* FA: fatty acids; NA: n-alkanes; CT: cholesterol
} 
Table 3. Element analyses of the cake layer in MBR-NPs and MBR-Blank (Wt(\%))

\begin{tabular}{ccccccccccc}
\hline Element & $\mathrm{C}$ & $\mathrm{O}$ & $\mathrm{Na}$ & $\mathrm{Mg}$ & $\mathrm{Al}$ & $\mathrm{Si}$ & $\mathrm{K}$ & $\mathrm{Ca}$ & $\mathrm{Ti}$ & $\mathrm{Fe}$ \\
MBR-NPs & 32.63 & 26.36 & 0.15 & 0.24 & 0.37 & 36.79 & 0.09 & 0.74 & 0.21 & 0.43 \\
MBR-Blank & 25.58 & 26.70 & 0.31 & 0.49 & 0.21 & 44.61 & 0.12 & 1.30 & - & 0.67 \\
\hline
\end{tabular}




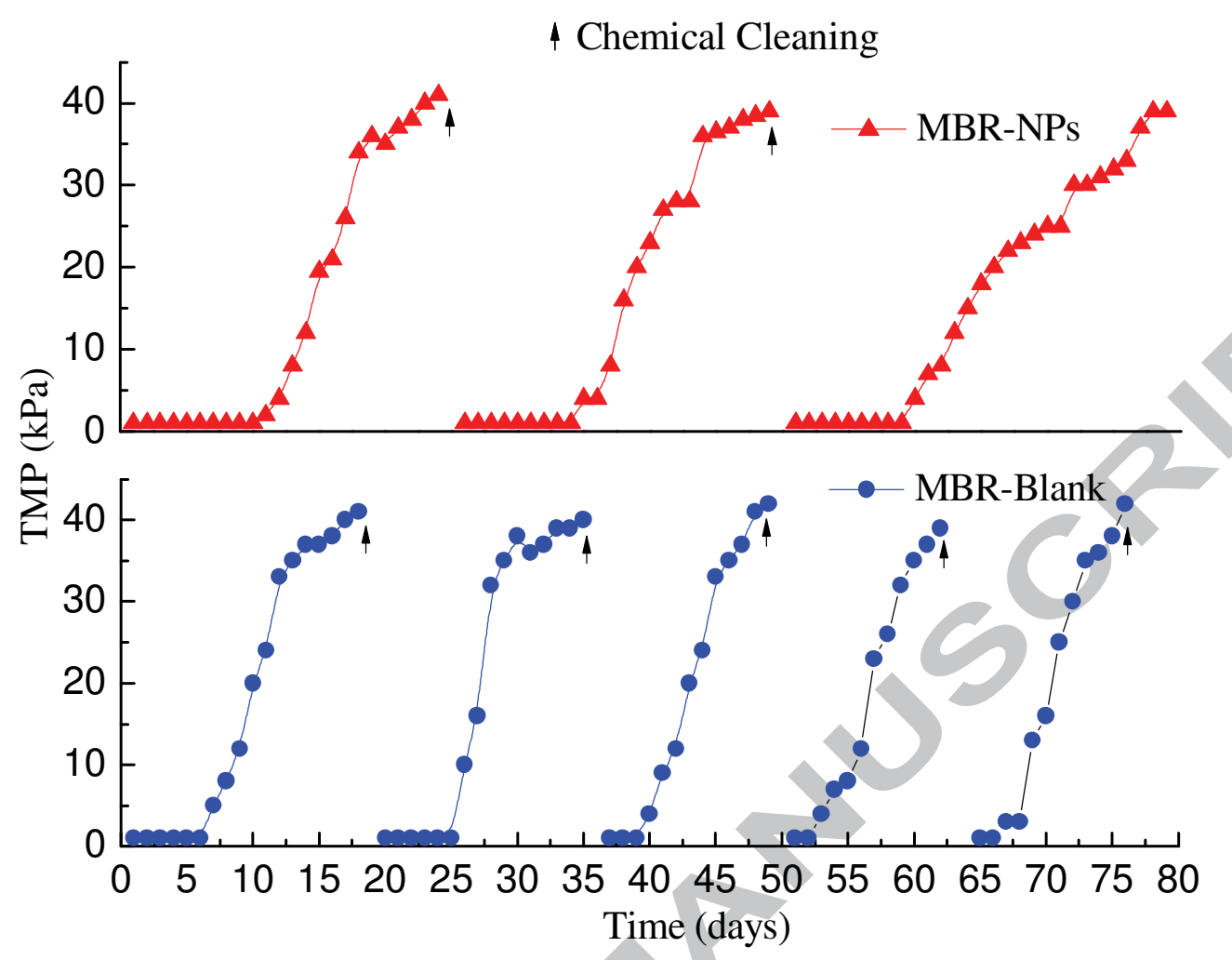

Fig. 1. TMP variation of MBR-NPs and MBR-Blank 

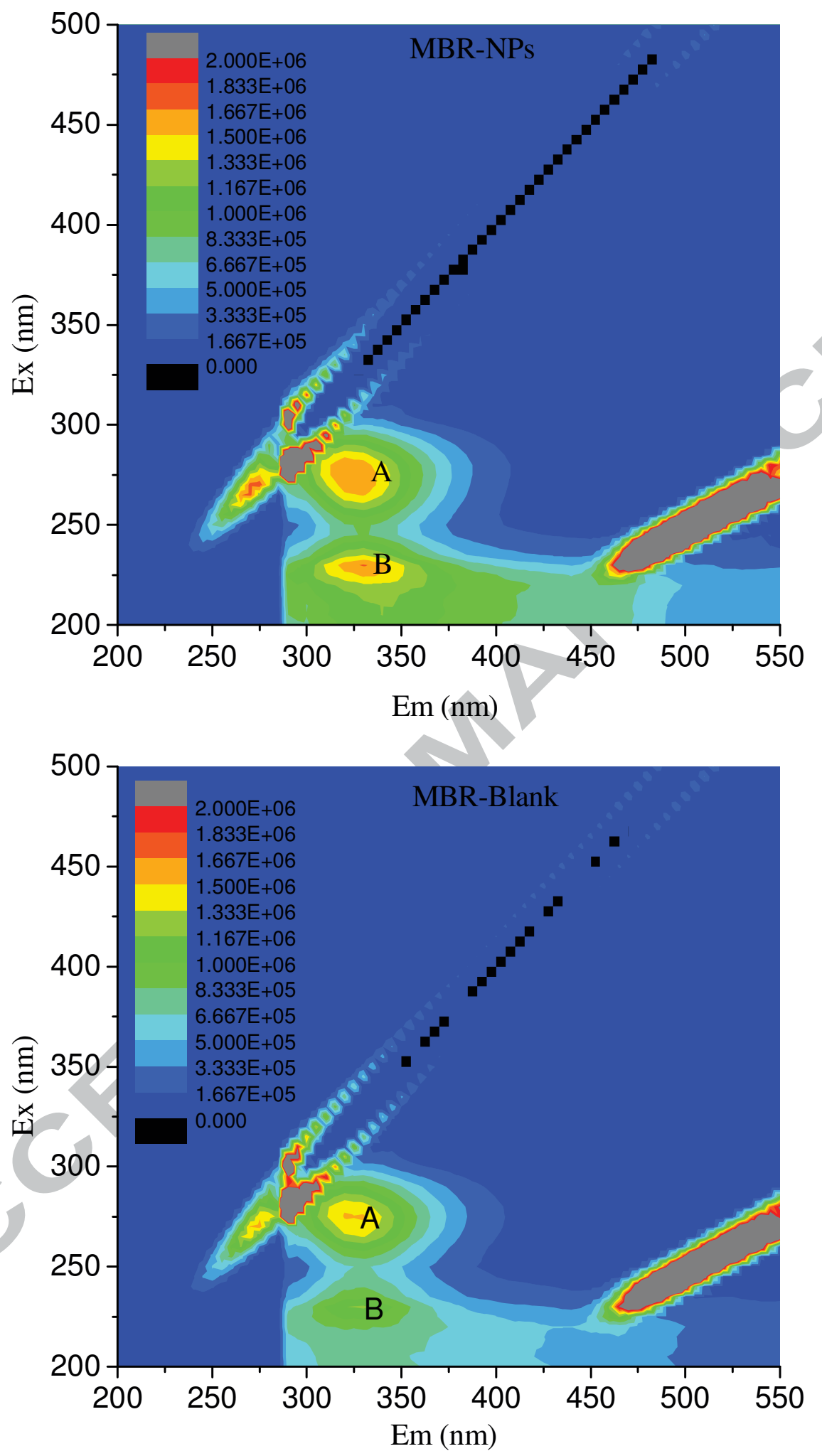

Fig. 2. EEM fluorescence spectra of biopolymers in cake layer 


\section{Highlights}

- Effects of suspended $\mathrm{TiO}_{2}$ nanoparticles on cake layer formation in MBR were studied

- $\mathrm{TiO}_{2}$ NPs aggravated membrane pore blocking but postponed cake layer fouling.

- $\mathrm{TiO}_{2} \mathrm{NPs}$ affected the distribution of the organic and the inorganic in cake layer

- Line-analysis and dot map of EDX were firstly used to identify cake layer structure

- Element distribution of cross-section cake layer, especially inner, was disclosed 


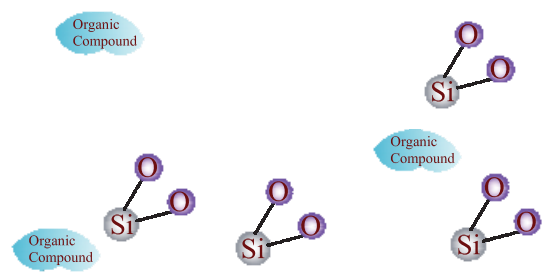

Membrane Surface

$\underset{\substack{\text { Organic } \\ \text { Compound }}}{\mathrm{O}}$

$I_{\mathrm{Ti}}^{\mathrm{O}}-\mathrm{O}$<smiles>O[Te]OB1CO1</smiles>

$T_{\mathrm{Ti}}^{\mathrm{O}}-\mathrm{O}$<smiles>O=[Ti]O</smiles>

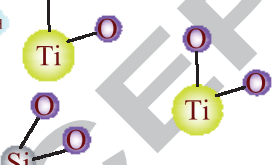

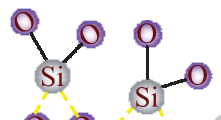

Organic 0 Oo 0

Si

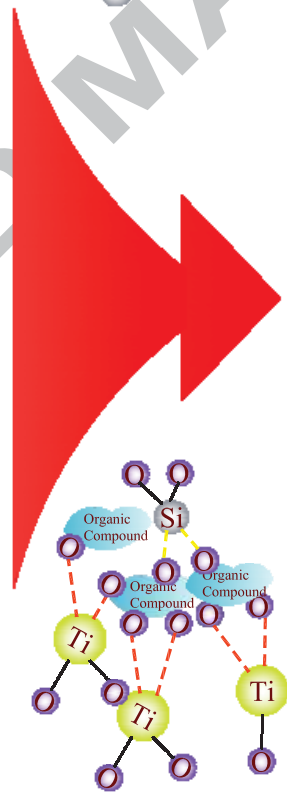

${ }_{0}^{\mathrm{Ti}}$

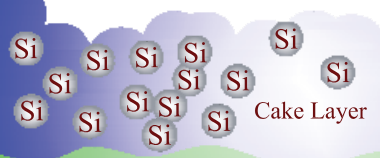
Membrane Surface

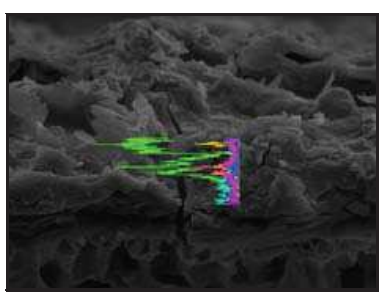

요
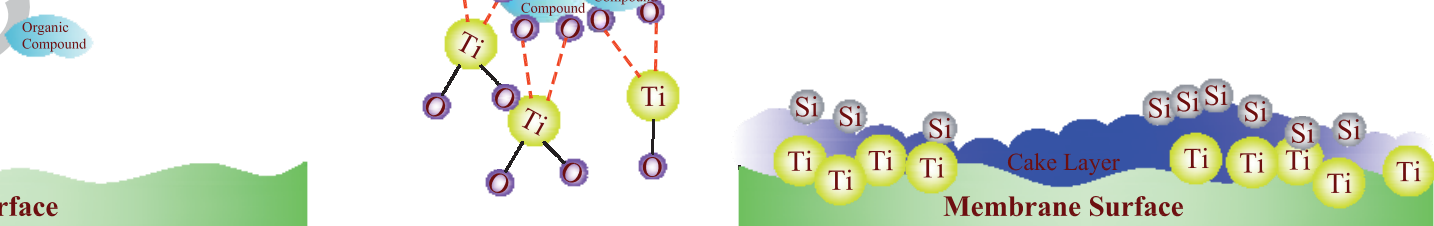